\title{
Quantitative and Qualitative Assessment of Verbal Fluency in Amnestic Mild Cognitive Impairment
}

Amnestik Hafif Kognitif Bozuklukta Sözel Akıcılık Becerilerinin Kantitatif ve Kalitatif Olarak Değerlendirilmesi

\author{
(1) Tuğçe Çabuk1 , (1) Şükrü Torun², (1) Demet Özbabalık Adapınar 3 \\ ${ }^{1}$ Bilkent University Faculty of Economics, Administrative and Social Sciences, Department of Psychology and National Magnetic Resonance \\ Research Center UMRAM, Ankara, Turkey \\ 2Anadolu University Faculty of Health Sciences, Department of Speech-Language Therapy and Unite of Cognitive Neuroscience and \\ Neurocreative Music Therapy, Eskisehir, Turkey \\ $3 \mathrm{MD}$, Eskisehir, Turkey
}

\begin{abstract}
Objective: The objective of this research was to compare the verbal fluency skills of patients diagnosed as having amnestic mild cognitive impairment (aMCI) with the participants without neurologic or psychiatric problems through quantitative and qualitative analysis, and to determine in which aspects patients with aMCI differed from the control group.

Materials and Methods: The sample of this study consisted of 20 individuals who presented to Özel Acrbadem Eskisehir Hospital with the symptom of forgetfulness and were diagnosed as having aMCI, and a healthy control group of the same size $(\mathrm{n}=20)$. All participants were administered preplanned verbal fluency tests that are valid and reliable, specifically for the mother language. Intergroup comparisons were made in the light of quantitative and qualitative assessments. Through the quantitative analysis, the total number of words produced in a limited amount of time under certain conditions was evaluated, and through the qualitative analysis, clustering and switching skills and error patterns such as perseveration and category violation were assessed.

Results: It was determined that the aMCI group showed a deterioration in verbal fluency skills, and individuals with aMCI had significantly lower scores on both phonemic $(\mathrm{u}=296.5, \mathrm{p}<0.05)$ and semantic $(\mathrm{u}=296, \mathrm{p}<0.05)$ verbal fluency tests when compared with the control group. In terms of the clustering extent and category violation, there was no significant difference between the groups in both phonemic and semantic categories ( $p>0.05$ for all comparisons). In phonemic verbal fluency tests, word switching skills of the patient group were significantly lower than those of the control group ( $u=279, \mathrm{p}<0.05)$. In the semantic fluency test, the perseveration ratio was significantly higher in the aMCI group than in the control group $(\mathrm{u}=96.5, \mathrm{p}<0.05)$.
\end{abstract}

Conclusion: The results support the view that verbal fluency tests are one of the effective ways of distinguishing a healthy old-aged individual from an individual with aMCI.

Keywords: Verbal fluency, clustering, switching, perseveration, amnestic mild cognitive impairment

Öz

Amaç: Bu çalışmanın amacı amnestik hafif kognitif bozukluk (aHKB) tanısı almış olgular ile herhangi bir nörolojik ve psikiyatrik sorunu olmayan katılımcıları sözel akıcılık becerileri açısından niceliksel ve niteliksel analizlerle karşılaştırmak ve aHKB hastalarının kontrol grubundan hangi alanlarda farklılık gösterdiğini belirlemektir.

Gereç ve Yöntem: Bu çalışmanın evreni, Özel Acıbadem Eskişehir Hastanesi'ne unutkanlık şikayeti ile başvuran ve aHKB tanısı alan 20 kişi ve aynı sayıdaki $(n=20)$ sağlıklı bir kontrol grubundan oluşmuştur. Tüm katılımcılara daha önceden planlanan ve ana dile özgü geçerlilik ve güvenirliliği bulunan sözel akıcılık testleri uygulanmış, niceliksel ve niteliksel değerlendirmeler sonucunda gruplar arası karşılaştırmalar yapılmıştır. Niceliksel analizde verilen koşula uygun olarak belli sürede üretilen toplam sözcük sayısı, niteliksel analizde ise öbekleme ve geçiş yapma becerileri ile perseverasyon ve kategori ihlali gibi hata örüntüleri değerlendirilmiştir.

Bulgular: aHKB grubunda sözel akıcılık becerilerinin bozulma gösterdiği; aHKB’li bireylerin toplam sözcük sayısı bakımından hem fonemik (u=296,5, p<0,05) hem de semantik $(u=296, p<0,05)$ akıcılık testlerinde kontrol grubuna göre anlamlı düzeyde daha düşük puanlar elde ettiği belirlenmiştir. Öbekleme genişliğ

Address for Correspondence/Yazışma Adresi: Tuğçe Çabuk, Bilkent University Faculty of Economics, Administrative and Social Sciences, Department of Psychology and National Magnetic Resonance Research Center UMRAM, Ankara, Turkey

Phone: +90 3122903415 E-mail: tugce1cabuk@gmail.com ORCID: orcid.org/0000-0003-1881-1349

Received/Geliş Tarihi: 24.10.2019 Accepted/Kabul Tarihi: 31.03 .2020

${ }^{\circ}$ Copyright 2020 by Turkish Neurological Society

Turkish Journal of Neurology published by Galenos Publishing House. 


\section{Öz}

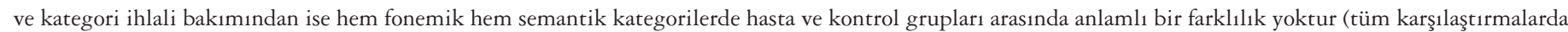

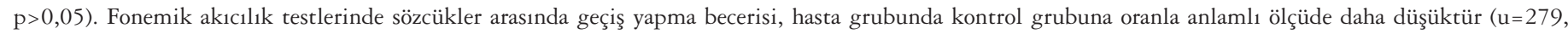
$\mathrm{p}<0,05)$. aHKB grubunun semantik akıc1lık testindeki perseverasyon oranı, kontrol grubundan anlamlı düzeyde daha fazladır ( $u=96,5, \mathrm{p}<0,05)$.

Sonuç: Sonuçlar, sözel akıcılık testlerinin sağlıklı yaşlı birey ve aHKB'li bireyi ayırt etmede etkili yollardan biri olduğunu destekler niteliktedir.

Anahtar Kelimeler: Sözel akıcılık, öbekleme, geçiş yapma, perseverasyon, amnestik hafif kognitif bozukluk

\section{Introduction}

In 1999, Petersen et al. $(1,2,3,4)$ termed mild cognitive impairment $(\mathrm{MCI})$ as is a clinical description for identifying a cognitive impairment worse than the standard, yet not severe enough for an individual to obtain a diagnosis of dementia. The current criteria for dementia incorporates the deterioration of several cognitive skills, such as memory, language, attention, visual-spatial, and executive functions, to the point of preventing an individual from living a fully independent daily life. By contrast, MCI occurs prior to any apparent detriment to an individual's daily life, functioning as the pathologic transition stage between "healthy" and "dementia". As yet, the standardized criteria and objective measurement for the diagnosis for MCI are insufficient for the diagnosis of MCI and for monitoring its potential to develop into dementia. We predict that verbal fluency tests may prove useful alongside advanced neurologic screening methods, and cerebrospinal fluid biomarkers can be monitored in this context $(5,6,7,8,9,10,11,12)$.

Consisting of counting words from a specific letter or category group within a limited time period, verbal fluency tests are frequently used in the practice of neuropsychology, and may incorporate challenging tasks measuring cognitive-motor processes, such as recall and articulation. Studies assessing verbal fluency performance during the course of MCI suggest significant cognitive differences between individuals with MCI and those without, suggesting that inadequate verbal fluency may be a symptom of the memory weakness accompanying the preclinical phases of Alzheimer's disease (1,5-27). At this point, it may be useful to focus on a subform of MCI termed amnestic MCI (aMCI) known to affect the memory functioning. Initially, MCI can be identified as aMCI according to the current terminology (3), and throughout the literature, it is generally accepted that the amnestic form of MCI represents the transition period between healthy ageing and Alzheimer's disease.

No studies have analyzed verbal fluency skills in aMCI, neither quantitatively nor qualitatively, in the relevant Turkish academic literature. In parallel with several international studies, this study predicts that a verbal fluency test might be useful for diagnosing aMCI, aiming to compare patients with aMCI in terms of verbal fluency skills through quantitative and qualitative analysis alongside a neurologically and psychatrically unimpaired control group.

\section{Materials and Methods}

\section{Research Model}

The research was conducted through a comparative descriptive model looking to examine the verbal fluency skills of both the aMCI patient group and the control group. We made intergroup comparisons by reviewing the fluency averages of $/ \mathrm{k}, \mathrm{a}, \mathrm{s} /$ sounds and the 'animals' category, and likewise, clustering and switching scores, perseveration, and violation errors.

In this study, quantitative and qualitative analysis scores for phonemic and semantic fluency constituted the dependent variable, and the presence of aMCI disorder constituted the independent variable.

\section{Participants of the Study}

The participants in this study, which was approved by Eskisehir Anadolu University Scientific Research and Publication Ethics Committee (date: 31.10.2017, number: 68215917-050.99), comprised a group of individuals with aMCI and another group of healthy individuals lacking any neurologic or psychiatric diagnoses. The aMCI group consisted of 20 participants diagnosed as having possible aMCI by Özel Acıbadem Eskisehir Hospital with processing Standardized Mini-Mental Test (SMMT) scores ranging between 24 and 28. The control group consisted of 20 voluntary participants with no reported neurologic or psychiatric health problems.

Groups were matched in terms of age, education, and sex. All participants were included in the study after signing an 'Informed Consent Form' approved by Eskişehir Anadolu University Scientific Research and Publication Ethics Committee. All participants in this study were literate, with ages ranging between 49 and 83 years. The demographic information of each participant was collected via a 'Participant Information Form', and their health information through a 'Health Status Information Form' (28).

Table 1 shows the information on demography, education, and sex of the participants (Table 1).

As a part of the mental assessment, all the participants underwent an SMMT, the validity and reliability of which has been previously assessed and substantiated Güngen et al. (29). This was administered to all participants in the study to assess each person's severity level and their potential for developing dementia. The SMMT scores of those in the aMCI group were fixed between 24 and 28 and therefore were not suspected of having dementia.

Categories, such as 'objects' or 'animals' are usually used in tests assessing semantic fluency. For our research, the category of animals was selected because it is known to be the least affected by factors such as education, culture, or language (30). On the phonemic fluency test, we used $/ \mathrm{k}$, a, s/ sounds because they constitute an alternative to the /f, a, s/ sounds frequently used in English and are preferred in Turkish clinical practice (31).

\section{Data Collection and Testing Process}

In total, this study contained four phonemic and semantic subtests. The participants were asked to produce as many words as they could think of in one minute for every letter and category. Before the test, the participants were told to not use proper nouns or inflexional suffixes that might change the meaning of the word, so any errors were evaluated as a violation. The participants' test 


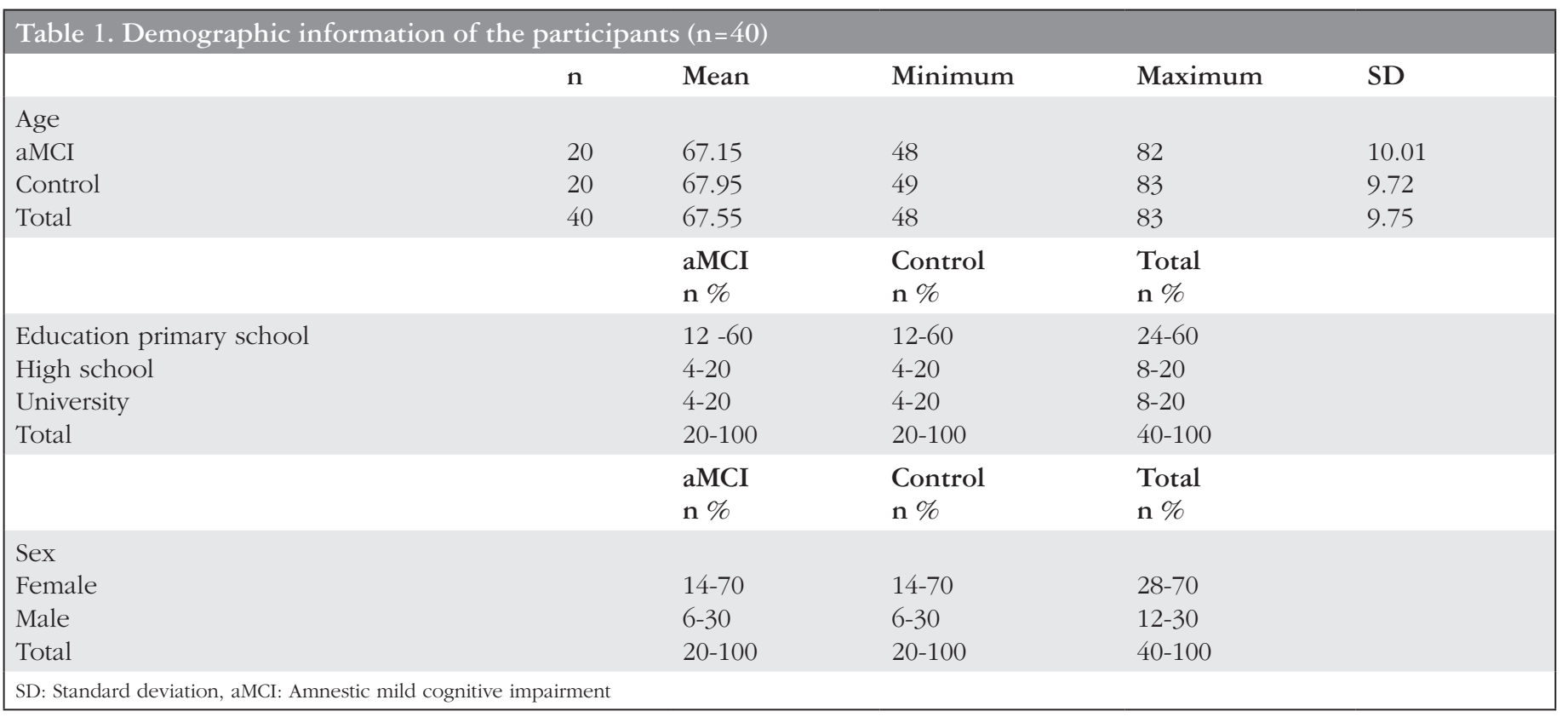

outputs of the participants were recorded and put into writing for later analysis.

\section{Data Analysis}

We analysed the outcomes, both quantitatively and qualitatively, within a framework of phonemic and semantic fluency, by calculating the mean total word count, clusterextent-based mean, switching mean, category violation mean, and perseveration mean. Using these means, we compared the experimental group and the control group.

In this research, we used the model developed by Troyer et al. (32). In their system, Troyer and Moscovitch (33) stated that verbal fluency errors indicated an intentional cognitive process, so we calculated the scores produced by clustering and switching, alongside scores including any recorded errors. During the calculation of the total word count mean, we excluded participant errors, such as perseveration and category violation. For the cluster-extent-based mean and switching mean, which fall under the scope of qualitative analysis, we included these errors in the calculation. Likewise, we individually calculated the means for perseveration and category violation errors.

In calculating the total word count, we excluded repetitions, synonyms, and out-of-category words, and to assess phonemic fluency, we excluded inflexional suffixes. In semantic fluency, if subcategories of a category were counted, the name of the category was not used so that we only considered the subcategory members; for example, if the participant referenced the individual category 'bird' and then continued with 'budgerigar', 'eagle', and 'hawk' in the calculation $(32,33)$.

In the phonemic fluency test, the model groups were clustered as follows: (a) phrases with the same first two letters, (b) phrases in which one letter changes, (c) rhyming phrases. In the semantic fluency test, clusters are grouped as village/farm animals, pets, woodland animals, and animals from specific zoologic categories (e.g. insects, birds, and fish).

Starting from the second word of every cluster, the average number of the clustering count constitutes the cluster-extentbased mean. We calculated this separately for both the phonemic and semantic tests, whereas the switching score was limited to the number of switching between cluster groups.

In phonemic fluency, here is an example of how we calculated clustering and switching using the result: "sabah, surat, sirk, saat, sabun, sert, serçe, sepet" with each underlined part indicating different clusters. Using our model, from this we can calculate:

Total number of words $=8$

Cluster-extent based mean $=(0+0+0+1+2) / 5=0.6$

So, if the cluster consisted of one word it was scored as 0 , but if it consisted of more than one word it was calculated by the ( $n$ 1) rule, and the switching number was calculated by taking the cluster number and subtracting 1. For intergroup comparisons, we obtained one single value by averaging the values of $\mathrm{k}$, a, and $\mathrm{s}$.

In assessing semantic fluency, here is an example of how we calculated clustering and switching, using: "ördek, kaz, aslan, kaplan, leopar, kedi, köpek, kartal, şahin, serçe, koyun, keçi, inek", with each underlined parts indicating different clusters. This produced:

Total number of words $=13$

Cluster-extent-based mean $=(1+2+1+2+2) / 5=1.4$

So again, if the cluster consisted of one word it was scored as 0 , but if it consisted of more than one word, it was calculated according to the (n-1) rule, with the switching number calculated by taking the cluster number and subtracting 1 .

Perseveration errors occur when the repetition of a word is produced under a specific category or with a specific letter. They are defined as a situation in which the brain selects an already used or random word because a new word cannot be 'easily' recalled from the semantic memory. For example, in the following sequence produced by a participant, "kedi, kalem, kumar, kelime, kedi, kupa, kumar" the underlined words indicate that there were two perseveration errors. In other words, the number of errors is equal to the number of repeated words.

Category violations occur when words, produced under a category or with a word, come out in a way that does not follow the predetermined rules. The rules included the use of proper nouns, 
inflexional suffixes by which the word does not gain a new meaning, and producing a word under another category instead of the target category. For instance, in the sequence "Ahmet abiye akıl açacak açacaklar atkı atkılar", the underlined words denote three category violation errors. As a more sensitive comparison parameter, we used a 'category violation rate' obtained by dividing the total number of words produced by the number of violations made.

\section{Statistical Analysis}

The data obtained in this study were analyzed using the Statistical Package for the Social Sciences (SPSS) Version 22.0 (SPSS Inc., Chicago, IL, USA) package program. We used the MannWhitney $\mathrm{U}$ test for studying differences between the groups because the variables did not fall within a normal distribution. For studying the effect of aMCI on phonemic and semantic test results in terms of total word count, cluster extent, and switching values, we used the forward stepwise conditional method for logistic regression analysis. When making an inference, we used $\mathrm{p}>0.05$ as the significance level. It was determined that there was a significant difference if $\mathrm{p}<0.05$.

\section{Results}

The findings and intergroup comparison results related to the aMCI and control groups obtained as the response of the research questions are given in the tables below.

In the phonemic fluency test, there was a significant difference between the groups in terms of the total word count $(u=296.5$, $\mathrm{p}<0.05)$. The total word count for the aMCI group was significantly lower than the control group. The mean for the total word count was 9.77 for the control group, whereas it was 6.2 for the aMCI group (Table 2 ).

No significant difference was observed between the groups in terms of cluster extent $(u=216, p>0.05)$. The phonemic characteristics of the groups showed similarities (Table 3 ).
There was a significant difference between the groups in terms of switching skills $(\mathrm{u}=279, \mathrm{p}<0.05)$. The switching mean was 6.25 for the control group in phonemic fluency, whereas it was 4.1 for the aMCI group. This situation indicates that patients with aMCI have poor switching skills between phonemic clusters (Table 4).

In the semantic fluency test, there was a significant difference between groups in terms of the total word count $(\mathrm{u}=296, \mathrm{p}<0.05)$. The total word count in semantic fluency for the aMCI group was significantly lower than the control group. The mean total word count was 16.40 for the control group, whereas it was 12.05 for the aMCI group. The aMCI group produced fewer animal words compared with the control group (Table 5).

There was no significant difference between the groups in terms of the cluster extent $(u=243, p>0.05)$. This finding indicates that in enumerating animals, aMCI patients show similar patterns to the control group in terms of producing words belonging to a subcategory (Table 6).

There was no significant difference between the groups in terms of switching skills in the semantic fluency test $(u=241$, $\mathrm{p}>0.05)$. The groups were similar in terms of switching between categories when listing animal names (Table 7).

There was no significant difference between groups in terms of category violation in the phonemic fluency test $(\mathrm{u}=144, \mathrm{p}>0.05)$. This finding shows that patients with aMCI make a similar number of violation errors in the phonemic fluency test (Table 8).

No significant difference was observed in terms of category violations in the semantic fluency test $(u=200, p>0.05)$. Both groups showed similar patterns in terms of category errors when listing animal names (Table 9).

In the phonemic fluency test, there was no significant difference between the groups in terms of perseveration errors $(\mathrm{u}=179, \mathrm{p}>0.05)$. Both groups had a similar number of repetition errors (Table 10).

Table 2. Total word count values and intergroup comparison in phonemic fluency test

\begin{tabular}{llllllll} 
& Mean & SD & Minimum & Maximum & \multicolumn{2}{c}{ Mann-Whitney U test } \\
& & & & & Mean rank & U & p \\
Control & 9.77 & 4.23 & 4.33 & 18.67 & 25.32 & 296.5 & $\mathbf{0 . 0 0 8}$ \\
aMCI & 6.2 & 3.22 & 1.33 & 12.33 & $\mathbf{1 5 . 6 8}$ & \\
SD: Standard deviation, aMCI: Amnestic mild cognitive impairment & & & \\
\hline
\end{tabular}

Table 3. Cluster extent and intergroup comparison in phonemic fluency test

\begin{tabular}{llllllll} 
& Mean & SD & Minimum & \multicolumn{2}{c}{ Maximum } & \multicolumn{2}{c}{ Mann-Whitney U test } \\
& & & & & Mean rank & U & p \\
Control & 0.55 & 0.46 & 0.03 & 1.78 & 21.3 & \\
aMCI & 0.43 & 0.33 & 0 & 1.21 & 19.70 & \\
SD: Standard deviation, aMCI: Amnestic mild cognitive impairment & & & \\
\hline
\end{tabular}

Table 4. Switching values and intergroup comparison in phonemic fluency test

\begin{tabular}{|c|c|c|c|c|c|c|c|}
\hline \multirow{2}{*}{\multicolumn{2}{|c|}{ Mean }} & \multirow[t]{2}{*}{$\mathrm{SD}$} & \multirow[t]{2}{*}{ Minimum } & \multirow[t]{2}{*}{ Maximum } & \multicolumn{3}{|c|}{ Mann-Whitney U test } \\
\hline & & & & & Mean rank & $\mathrm{U}$ & $\mathrm{p}$ \\
\hline Control & 6.25 & 3.06 & 2.33 & 12.76 & 24.45 & 279 & 0.033 \\
\hline
\end{tabular}


A significant difference was observed between the groups in terms of perseveration errors in the semantic fluency test $(u=96.5$, $\mathrm{p}<0.05$ ). Perseveration errors of the aMCI group were significantly higher than in the control group. The perseveration error value was 0.05 for the control group and 1.45 for the aMCI group in the semantic fluency test. This finding suggests that in the semantic fluency test, controls make fewer perseveration errors than patients with aMCI (Table 11).

The effect of the presence of aMCI on total word count, cluster extent, and switching parameter in verbal fluency tests is shown in the tables below.

Table 5. Total word count values and intergroup comparison in semantic fluency test

\begin{tabular}{llllllll} 
& Mean & SD & Minimum & Maximum & \multicolumn{2}{c}{ Mann-Whitney U test } \\
& & & & & Mean rank & U & p \\
Control & 16.40 & 2.70 & 12 & 22 & 25.30 & & \\
aMCI & 12.05 & 5.11 & 5 & 20 & 15.70 & \\
SD: Standard deviation, aMCI: Amnestic mild cognitive impairment & & & \\
\hline
\end{tabular}

Table 6. Cluster extent and intergroup comparison in semantic fluency test

\begin{tabular}{|c|c|c|c|c|c|c|c|}
\hline \multirow{2}{*}{\multicolumn{2}{|c|}{ Mean }} & \multirow[t]{2}{*}{$\mathrm{SD}$} & \multirow[t]{2}{*}{ Minimum } & \multirow[t]{2}{*}{ Maximum } & \multicolumn{3}{|c|}{ Mann-Whitney U test } \\
\hline & & & & & Mean rank & $\mathbf{U}$ & $\mathrm{p}$ \\
\hline Control & 1.18 & 0.61 & 0.42 & 3 & 22.65 & 243 & 0.25 \\
\hline
\end{tabular}

Table 7. Switching values and intergroup comparison in semantic fluency test

\begin{tabular}{llllllll} 
& Mean & SD & Minimum & Maximum & \multicolumn{2}{c}{ Mann-Whitney U test } \\
& & & & & Mean rank & U & \\
Control & 7.5 & 1.98 & 3 & 11 & 22.55 & 18.45 & \\
aMCI & 6.45 & 3.28 & 2 & 13 & & \\
SD: Standard deviation, aMCI: Amnestic mild cognitive impairment & & & \\
\hline
\end{tabular}

Table 8. Category violation values and intergroup comparison in phonemic fluency test

\begin{tabular}{|c|c|c|c|c|c|c|c|}
\hline & Mean & SD & Minimum & Maximum & \multicolumn{3}{|c|}{ Mann-Whitney $U$ test } \\
\hline Control & 0.52 & 0.54 & 0 & 0.67 & 17.7 & 144 & 0.13 \\
\hline
\end{tabular}

Table 9. Category violation values and intergroup comparison in semantic fluency test

\begin{tabular}{llllllll} 
& Mean & SD & Minimum & Maximum & \multicolumn{2}{l}{ Mann-Whitney U test } \\
& & & & Mean rank & U & p \\
Control & 0 & 0 & 0 & 0 & 20.50 & 200 & 1 \\
aMCI & 0 & 0 & 0 & 0 & 20.50 & \\
SD: Standard deviation, aMCI: Amnestic mild cognitive impairment & & & \\
\hline
\end{tabular}

Table 10. Perseveration values and intergroup comparison in phonemic fluency test

\begin{tabular}{llllllll} 
& Mean & SD & Minimum & Maximum & \multicolumn{2}{c}{ Mann-Whitney U test } \\
& & & & & Mean rank & U & 179.5 \\
Control & 0.18 & 0.35 & 0 & 1.33 & 19.48 & 0.58 \\
aMCI & 0.30 & 0.53 & 0 & 1.67 & 21.52 & \\
SD: Standard deviation, aMCI: Amnestic mild cognitive impairment & & & \\
\hline
\end{tabular}


The effect of aMCI on semantic and phonemic fluency tests turned out to be statistically significant $(\mathrm{p}<0.05)$ (Table 12).

The presence of aMCI affects the total word count in the semantic test $(p<0.5)$. Being a patient shows itself with a greater decline in the total number of words $(\operatorname{Exp}(B)=0.764)$. The aMCI group was less successful in semantic fluency tests than in phonemic fluency tests (Table 13).

The presence of aMCI affects switching skills on the phonemic test $(\mathrm{p}<0.05)$ (Table 14).

The presence of aMCI affects the switching parameter in the phonemic test $(\mathrm{p}<0.05)$. Being a patient shows itself with a decline in the number of switching on the phenomic test (Exp $(B)=0.701)($ Table 15).

The values of the cluster extent are the variables that are not directly affected by the presence of aMCI (p>0.05) (Table 16).

\section{Discussion}

This study supports the idea that individuals with MCI experience quantitative and qualitative loss in terms of their verbal fluency skills, and demonstrate that the presence of MCI, in both phonemic and semantic fluency, will affect the verbal fluency scores except for cluster extent. Through comparing the mean total word count of the participants with and without aMCI, we determined that in contrast to the control group, the aMCI group presented a lower success rate in both types of fluency. Many studies in the literature emphasize that the word production in both verbal fluency categories decreases with MCI, arguing that it is one of the best and most effective ways of discerning healthy old-aged individuals from those with MCI $(5,6,7,8,9,10,11,12)$. By contrast, when focusing on semantic fluency using fruit and animal categories, Karrasch et al. (34) and Radanovic et al. (35) observed no significant difference between the MCI and control

Table 11. Perseveration values and intergroup comparison in semantic fluency test

\begin{tabular}{llllllll} 
& Mean & SD & Minimum & Maximum & \multicolumn{2}{c}{ Mann-Whitney U test } \\
& & & & & Mean rank & U & P \\
Control & 0.05 & 0.22 & 0 & 1 & 15.32 & \\
aMCI & 1.45 & 1.91 & 0 & 1 & 25.68 & \\
SD: Standard deviation, aMCI: Amnestic mild cognitive impairment & & & \\
\hline
\end{tabular}

Table 12. Chi-square test results of the presence of aMCI in phonemic and fluency tests in terms of total word count

\begin{tabular}{llll} 
& Chi-square & SD & p \\
Step (1) & 10.27 & 1 & $\mathbf{0 . 0 0 1}$ \\
Block & 10.27 & 1 & $\mathbf{0 . 0 0 1}$ \\
Model & 10.27 & 1 & $\mathbf{0 . 0 0 1}$ \\
SD: Standard deviation, aMCI: Amnestic mild cognitive impairment & & & \\
\hline
\end{tabular}

Table 13. The effect of the presence of aMCI on total word count

Veriables in the model

\begin{tabular}{lllllll} 
& B & SH & Wald & SD & p & Exp (B) \\
Total word count (Semantic) & -0.269 & 0.101 & 7.070 & 1 & $\mathbf{0 . 0 0 8}$ & 0.764 \\
Constant & 3.894 & 1.544 & 6.358 & 1 & $\mathbf{0 . 0 1 2}$ & 49.113 \\
SD: Standard deviation, aMCI: Amnestic mild cognitive impairment & & & & & \\
\hline
\end{tabular}

Table 14. Chi-square test results of the presence of aMCI in phonemic and semantic fluency results in terms of switching parameter

\begin{tabular}{|c|c|c|c|}
\hline & Chi-square & SD & $\mathrm{p}$ \\
\hline Step (1) & 6.181 & 2 & 0.045 \\
\hline Block & 6.181 & 2 & 0.045 \\
\hline Model (switching-phonemic) & 6.181 & 2 & 0.045 \\
\hline
\end{tabular}

Table 15. The effect of the presence of aMCI on switching skills

Variables in the model

\begin{tabular}{lllllll} 
& B & SH & Wald & SD & p & Exp (B) \\
Switching (phonemic) & -0.355 & 0.173 & 4.211 & 1 & $\mathbf{0 . 0 4 0}$ & 0.701 \\
Constant & 1.062 & 0.961 & 1.221 & 1 & $\mathbf{0 . 2 6 9}$ & 2.892 \\
SD: Standard deviation, aMCI: Amnestic mild cognitive impairment & & & & \\
\hline
\end{tabular}


Table 16. The effect of the presence aMCI of on cluster extent

Variables in the model

\begin{tabular}{llll|} 
& Score & SD & p \\
Step 0 cluster extent (phonemic) & 0.796 & 1 & 0.372 \\
Cluster extent (semantic) & 2.650 & 1 & 0.104 \\
All statistics & 3.300 & 2 & 0.192 \\
SD: Standard deviation, aMCI: Amnestic mild cognitive impairment & \\
\hline
\end{tabular}

groups in their study. These researchers stated that verbal fluency tests provided more accurate results for diagnosing Alzheimer's disease, but were not noticeably useful for differentiating individuals with and without MCI. This requires further monitored studies to reveal the potential of verbal fluency defects for predicting Alzheimer's disease.

In the section in which we qualitatively evaluated verbal fluency skills, the aMCI group performed poorly when switching skills in phonemic fluency, yet no significant difference was observed when switching skills in semantic fluency skills. Accordingly, it can be said that those with aMCI were less able than the controls to switch between different categories. For the cluster extent, we observed no significant difference between the groups. Our research suggests the possibility that aMCI may not cause deficiency when creating a categorical cluster extent.

The literature includes different results and opinions as to the effect of MCI on qualitative skills in verbal fluency. Murphy et al. (19) discovered a significant decrease in semantic fluency when an individual used clustering and switching skills, but did not observe a similar situation in phonemic fluency. In another study, it was concluded that people with MCI had difficulty in constructing clusters when thinking about semantic relations instead of lexical representation (5). In their research including subcategories of MCI, Weakly al. (27) obtained results indicating that their singledomain amnestic MCI group scored lower than their control group when switching skills in both semantic and phonemic fluency, additionally observing that their multiple-domain amnestic MCI group only declined in phonemic fluency when switching skills. Bertola et al. (14) compared the clustering and switching skills of individuals with single-domain amnestic MCI, multiple-domain amnestic MCI, Alzheimer's disease, and older but cognitively unimpaired Brazilian individuals. These researchers determined that semantic impairment was somewhat visible in individuals living with MCI, but not dementia, and correspondingly, their switching skills in semantic fluency indicated a considerable decrease. When we consider that switching skills are related to mental flexibility including the ability to perform new searches and information recall in semantic memory, it can be argued that deterioration may likewise have also begun in executive functions of MCI individuals.

In our research, although no significant difference was found between the groups in terms of category violation, which is also a qualitative evaluation, it was determined that the group with aMCI engaged in more perseveration in semantic fluency. There are no studies in the relevant Turkish academic literature focusing on the increasing error patterns such as category violation during the semantic fluency performance of the MCI group as an important indicator of potential dementia. Within the relevant English academic literature, new studies support our argument, but concentrating on semantic fluency rather than phonemics (14). This reinforces our results suggesting a higher perseveration error rate is observed more frequently in individuals with MCI. For example, Stokholm et al. (36) discovered that as people age, an impairment in semantic fluency can be more apparent than one in phonemic fluency. Cottingham et al. (37) studied participants with aMCI, who are known to be at the risk of developing Alzheimer's disease, underlining their weakness and the impairment in semantic fluency. In another study, individuals with aMCI were found to produce fewer words and more errors (19). In Kave and Heinik (38) recent research conducted with people living with Alzheimer's disease, MCI, and subjective memory problems, it was highlighted that perseveration errors were mostly seen in individuals with Alzheimer's disease with no significant difference observed between MCI and subjective memory problem groups, yet even in those groups, perseveration errors increased proportionally and alongside memory problems and the severity of impairment. In light of these findings, it can be said that perseveration errors are closely related to impairment in the inhibition mechanism, working memory, and executive functions such as switching skills. There is a need for further comparative monitoring research on the predictive value of perseveration errors in aMCI and verbal fluency defect patterns developing into Alzheimer's disease.

\section{Study Limitations}

One limitation of this research is that its participants were restricted to Turkish-speaking residents of Eskisehir and Ankara. Additionally, only an amnestic group was chosen as a subcategory of MCI, with 20 individuals with aMCI and 20 individuals lacking any form of MCI. Furthermore, in this research we used only one neuropsychological assessment tool, focusing on verbal fleuncy. For future research, it might prove beneficial to test patients with aMCI with a wider variety of neuropsychological assessment tools for further and more detailed analysis of our hypothesis.

\section{Conclusion}

In this study comparing MCI individuals with neurologically and psychologically healthy individuals, we have taken into consideration both quantitative analysis, including the total score of verbal fluency tests, and qualitative analysis, including clustering, switching, and patterns of error. Similar to the relevant literature, it was discovered that the aMCI group performed worse than the control group in terms of verbal fluency skills. It was determined that those in the aMCI group achieved a lower total word count and were less successful at switching skills on phonemic and semantic fluency tests than individuals with no MCI. No significant difference was observed between the groups in terms of their cluster-extentbased mean score. When evaluating the performances on the tests, we found that the aMCI group obtained lower scores in semantic fluency than in phonemic fluency. When taking into account the error patterns between both groups, the aMCI group and the control group achieved similar levels of category violation, whereas, in semantic fluency, the aMCI group obtained more perseveration errors than the control group. We believe that our findings have critical importance concerning the potential for dementia associated with MCI and that perseveration errors may be a useful parameter for identifying individuals with differing levels of semantic memory problems.

For further research, we suggest a more comprehensive study by using a larger sample size and with homogeneity between the groups. Similarly, we believe a comparison between various calculating methods that are used in qualitative analysis of verbal 
fluency could prove valuable for determining the usability of qualitative analysis in verbal fluency tests. Moreover, verbal fluency analyses directed at other subcategories of MCI can be studied to determine their importance for diagnostic identification.

\section{Ethics}

Ethics Committee Approval: Eskisehir Anadolu University Scientific Research and Publication Ethics Committee (date: 31.10.2017, number: 68215917-050.99).

Informed Consent: All participants were included in the study after signing an 'Informed Consent Form' approved by Eskişehir Anadolu University Scientific Research and Publication Ethics Committee.

Peer-review: Externally and internally peer-reviewed.

\section{Authorship Contributions}

Surgical and Medical Practices: T.Ç., Concept: T.Ç., Ş.T., D.Ö.A., Design: T.Ç., Ş.T., Data Collection or Processing: T.Ç., Ş.T., Analysis or Interpretation: T.Ç., Ş.T., D.Ö.A., Literature Search: T.Ç., Ş.T., Writing: T.Ç., Ş.T., D.Ö.A.

Conflict of Interest: No conflict of interest was declared by the authors.

Financial Disclosure: The authors declared that this study received no financial support.

\section{References}

1. Petersen RC, Smith GE, Waring SC, et al. Mild cognitive impairment: clinical characterization and outcome. Arch Neurol 1999;56:303-308.

2. Burns A, Zaudig M. Mild cognitive impairment in older people. Lancet 2002;360:1963-1965.

3. Petersen RC, Negash S. Mild cognitive impairment: an overview. CNS Spectrums 2008;13:45-53

4. Petersen RC. Mild cognitive impairment. N Engl J Med 2011;364:22272234.

5. Nutter-Upham KE, Saykin AJ, Rabin LA, et al. Verbal fluency performance in amnestic MCI and older adults with cognitive complaints. Arch Clin Neuropsychol 2008;23:229-241.

6. Brandt J, Manning KJ. Patterns of wordlist generation in mild cognitive impairment and Alzheimer's disease. Clin Neuropsychol 2009;23:870-879.

7. Standish IM, Molloy DW, Cunje A, Lewis DL. Do the ABCS 135 short cognitive screen and its subtests discriminate between normal cognition, mild cognitive impairment and dementia? Int J Geriatr Psychiatry 2007;22:189-194.

8. Clark DG, McLaughlin PM, Woo E, et al. Novel verbal fluency scores and structural brain imaging for prediction of cognitive outcome in mild cognitive impairment. Alzheimers Dement (Amst) 2016;1:1-10.

9. Ramanan S, Narayanan J, D'Souza TP, Malik KS, Ratnavalli E. Total output and switching in category fluency successfully iscriminates Alzheimer's disease from Mild Cognitive Impairment, but not from frontotemporal dementia. Dement Neuropsychol 2015;9:251-257.

10. Mirandez MR, Aprahamian I, Talib LL, Forlenzo OV, Radanovic M. Multiple category verbal fluency in mild cognitive impairment and correlation with CSF biomarkers for Alzheimer's disease. Int Psychogeriatr 2017;29:949-958.

11. Vaughan MR, Coen RF, Kenny R, Lawlor BA. Semantic and phonemic verbal fluency discrepancy in mild cognitive impairment: potential predictor of progression to Alzheimer's disease. JAGS 2018;66:755-759.

12. Gustavson ED, Elman J, Panizzon MS, et al. Semantic fluency predicts sixyear progression to mild cognitive impairment in middle-aged men. doi: $10.1101 / 659417$

13. Bennett DA, Wilson RS, Schneider JA, et al. Natural history of mild cognitive impairment in older persons. Neurology 2002;59:198-205.

14. Bertola L, Lima MLC, Romano-Silva MA, et al. Impaired generation of new subcategories and switching in a semantic verbal fluency test in older adults with mild cognitive impairment. Front Aging Neurosci 2014;6:141.

15. Bschor T, Kuhl KP, Reischies FM. Spontaneous speech of patients with dementia of the Alzheimer type and mild cognitive impairment. Int Psychogeriatr 2001;13:289-298.
16. Dwolatzky T, Whitehead V, Doniger GM, et al. Validity of a novel computerized cognitive battery for mild cognitive impairment. BMC Geriatr 2003;3:4

17. Geslani D, Tierney M, Herrmann N, Szalai J. Mild cognitive impairment: an operational definition and its conversion rate to Alzheimer's disease. Dement Geriatr Cogn Dis 2005;19:383-389.

18. Grundman M, Petersen RC, Ferris SH, et al. Mild cognitive impairment can be distinguished from Alzheimer disease and normal aging for clinical trials. Arch Neurol 2004;61:59-66.

19. Murphy KJ, Bich JB, Troyer AK. Verbal fluency patterns in amnestic mild cognitive impairment are characteristic of Alzheimer's type dementia. J Int Neuropsychol Soc 2006;12:570-574.

20. Östberg P, Fernaeus SE, Hellström A, Bogdanovic N, Wahlund LO. Impaired verb Fuency: a sign of mild cognitive impairment. Brain and Language 2005;95:273-279.

21. Price SE, Kinsella G, Ong B, et al. Semantic verbal fluency strategies in amnestic mild cognitive impairment. Neuropsychology 2012;26:490-497.

22. Ribeiro F, de Mendonça A, Guerreiro M. Mild cognitive impairment: deficits in cognitive domains other than memory. Dement Geriatr Cogn Dis 2006;21:284-290.

23. Saxton J, Lopez OL, Ratcliff G, et el. Preclinical Alzheimer disease: Neuropsychological test performance 1.5 to 8 years prior to onset. Neurology 2004;63:2341-2347.

24. Smith EG, Bondi MW. Mild cognitive impairment and dementia. Oxford: Oxford University Press, 2013.

25. Tabert M, Manly JJ, Liu X, et al. Neuropsychological prediction of conversion to Alzheimer disease in patients with mild cognitive impairment. Arch Gen Psychiatry 2006;63:916-924

26. Taler V, Philips NA. Language performance in Alzheimer's disease and mild cognitive impairment: a comparative review. J Clin Exp Neuropsychol 2008;30:501-556.

27. Weakly A, Schmitter-Edgecombe M, Anderson J. Analysis of verbal fluency ability in amnestic and non-amnestic mild cognitive impairment. Arch Clin Neuropsychol 2013;28:721-731.

28. Yılmaz N. Kürtçe-Türkçe konuşan iki dilli yetişkin bireylerin sözel akıcılık becerilerinin incelenmesi (Msc Thesis). Eskişehir: Anadolu Üniversitesi Sağlık Bilimleri Enstitüsü Dil ve Konuşma Terapisliği Anabilim Dalı; 2016

29. Güngen C, Ertan T, Eker E, Yaşar R, Engin F. Standardize mini mental testin türk toplumunda hafif demans tanısında geçerliliği ve güvenirliği. Türk Psikiyatri Dergisi 2002;13:273-281.

30. Ardilla A, Ostrosky-Solis F, Bernal B. Cognitive testing toward the future: The example of Semantic Verbal Fluency (ANIMALS). Int J Psychol 2006; $41: 324-332$.

31. Tunçer AM. Türkçe konuşan yetişkin popülasyonunun sözel akıcılık becerilerinin yaş, eğitim ve cinsiyete göre incelenmesi ve sözcük normlarının oluşturulması (Doktora Tezi). Eskişehir: Anadolu Üniversitesi Sağlık Bilimleri Enstitüsü Dil ve Konuşma Terapisliği Anabilim Dalı; 2011.

32. Troyer AK, Moscovitch M, Winocur G. Clustering and switching as two components of verbal fluency: evidence from younger to older healthy adults. Neuropsychology 1997;11:138-146

33. Troyer AK, Moscovitch M. Cognitive processes of verbal fluency tasks. In: Poreh AM (ed). Studies on neuropsychology, neurology and cognition. The quantified process approach to neuropsychological assessment. Philadelphia: Taylor \& Francis, 2006:143-160

34. Karrasch M, Sinervä E, Grönholm P, Rinne J, Laine M. CERAD test performances in amnestic mild cognitive impairment and Alzheimer's disease. Acta Neurol Scand 2005;111:172-179.

35. Radanovic M, Diniz BS, Mirandez RM, et al. Verbal fluency in the detection of mild cognitive impairment and Alzheimer's disease among Brazilian Portuguese speakers: the influence of education. Int Psychogeriatr 2009;21:1081-1087.

36. Stokholm J, Jörgensen K, Vogel A. Performances of five verbal fluency tests in a healthy, elderly, Danish sample. Aging Neuro And Cog 2013;20:22-23.

37. Cottingham M, Hawkins KA. Verbal fluency deficits co-occur with memory deficits in geriatric patients at risk for dementia: Implications for the concept of mild cognitive impairment. Behav Neurol 2010;22:73-79.

38. Kave G, Heinik J. Cognitive correlates of perseverations in individuals with memory impairment. Arch Clin Neuropsychol 2017;32:63-70. 